\title{
„Pop-up“ Urban Allotment Gardens - How Temporary Urbanism Embraces the Garden Concept
}

\section{Sara Ursić}

Institute of Social Sciences Ivo Pilar, Zagreb, Croatia e-mail:sara.ursic@pilar.hr

\section{Rašeljka Krnić}

Institute of Social Sciences Ivo Pilar, Zagreb, Croatia e-mail: raseljka.krnic@pilar.hr

\section{Anka Mišetić}

University of Zagreb, Faculty of Architecture, School of Design, Croatia e-mail:anka.misetic@arhitekt.hr

\begin{abstract}
In the contemporary urban context it can be argued that the concept and practices of urban gardens represent one of the key tools for achieving the universal urban goal - sustainability and smartness. Functions of contemporary urban gardens are part of a new urban paradigm: caring for the environment, rediscovering social interaction and reconnecting with nature.
\end{abstract}

At the same time we are witnessing the emergence of temporary urbanism within urban space involving the provisional usage of unused spaces for a wide range of activities. It allows for the transformation of traditional categories (e.g. gardens, parks) into a hyper contemporary category of urban space that contains desirable characteristics such as availability, mobility, re-use and temporality, i.e. urban gardens that sprout or 'pop up' as part of civil society initiatives or festival events.

Temporary urbanism and pop-up gardens are considered through allotment gardens in Croatia. They present the revival of urban agriculture and are explored in relation to their polyfunctional character that addresses economic, ecological and social questions. 
Returning to the statement thatcontemporary urban gardens are part of a new urban paradigm and bearing in mind the bipolarity of urban gardening, the research analyses the attitudes of students of architecture towards the concept, usage and design of urban gardens in several operational categories such as temporary-permanent, amateur-professional, bottom-up vs. top-down approach, space-place. Their roleoffuture designers and innovators who are expected to deliver sustainable urban forms is extremely important.

Key words: temporary urbanism, urban policy, urban gardens, place, space.

\section{Introduction}

Cities are such complex and dynamic places that are growing out of symbiotic connections between usually L or XL planning projects on the one side and more spontaneous everyday praxis of urban life. This, as we called it, a symbiotic relationship, is a base for city growth around the world. In the modern urban context, two global objectives are implemented in it at the local level: sustainability and smartness. When talking about contemporary urbanism, it is impossible to skip the two mentioned concepts that, along with revitalization, regeneration, re - use and re - imagining, represent know - how urbanism today (Elin, 1999; Duaney, 2015).After listing the requirements of thevitalcity, such as "city full of life, dynamism, cutting edge trends, public bealth and wealth" (Tunstorm, 2007:685), one realizes that the concept and praxis of urban gardens can integrate one of the key tools to achieve those, nearly universal, goals of each urban area and (local) community that resides in it. Being a permanent part of the urban tissue in various changing shapes, urban allotment gardens do not represent a completely new urban phenomenon, however, contemporary urban allotment gardens' functions are part of a new urban paradigm that includes concern for the environment, calls for rediscovering social interaction and new forms of socialization by returning to nature. The call for reorganization and the opening of abandoned, unused or decayed spaces in order to expand the public space, has long been a part of the research of urban studies in quest of socially sustainable development / transformation of urban space (Moore, 2015; Bagaeen,2006).,In response to the growth of vacant spaces within cities, greater attention has been drawn to alternative urban uses and the demarcation of areas where 'meanwhile activities' take place or colloquially termed 'meanwhile spaces'" (Moore-Cherry, 2016:2). At the same time Godot - like quest for authenticity, uniqueness and livability of a city bring into question urban planning scales.

New urban policies are reflected even in the popular culture. Critically acclaimed American TV series "Parks and Recreations" offer great example of the state, procedures and related social barriers that collide with concepts of green urbanism in everyday life. The story is built around a large hole that was left on the ground, Lot48, after investors fled from another more or less ambitious housing project. Transformation of unused urban space, the so-called pit, into the park is shown as the paradigmatically "impossible mission". Administrative mess, the relationship with the residents, ensuring the necessary budget are just some obstacles that the protagonist encounters through several seasons of the series .Vast space in the mid- 
dle of built neighborhood is being used as allotment garden, as camping site and as junk space until the pit is covered with land and then the second phase starts. To make long story short, building a park isnžt as simple as one could think.

In this paper the central issue is urban allotment gardens' functioning as re-imagined phenomenon in the city, in relation to the space-time aspect that contemporary types of urbanism deal with. In order to analyze contemporary urban allotment gardens as a part of new urban paradigm, and bearing in mind the often bipolar dimensions of urban gardening, research analyses architecture students' attitudes on concept, usage and design of urban gardens to consider operational categories such as temporary-permanent, amateur-professional, bottom-up-top down and space-place and their roles as designers and social innovators who are expected to deliver future sustainable urban forms. In this sense, the comparison of a park and a garden, along with their functions and positions they have in the whole of urban area, is inevitable. We were especially interested in the way students of architecture and urbanism perceive their roles and potential of modern cities.

The space-time aspect of 'the urban' in literature appears in various terms, one of which is temporary urbanism whose main objective is temporary use of space for a wide range of activities, ranging from formal to informal (Bishop and Williams, 2012). In order to learn that, we have analyzed concepts of parks and urban gardens, assuming that the park is something planned, permanent, public, large-scale, top down, and lacks subjectivity, while modern concept of allotment garden includes adjectives such as small scale, community oriented, unplanned or semi-planned, semi-public and bottom up. In terms of social identity parks can be connected to urban identity, and allotment gardens, because of their agricultural dimensions, to rural or folk identity.

\section{Aspects of Pop-up Urbanism}

Talking about urbanism means thinking of urbanism as a way of living, but also as a built environment (Wirth, 1938). By emphasizing some of the basic requirements of modern urbanism, such as sustainability and smartness, we can find a large number of theoretical concepts and examples that are divided according to the basic field they come from. Whether a starting point is ecological, technological, economic, political, architectural or social dimension, city urbanism nowadays seeks to satisfy those elementary requirements.Having in mind previously mentioned, if we are to explore the transformation of design and usage of urban greenery it is necessary to mention the concept of everyday life that de Certeau and Lefebvre have already identified as important aspect of social studies, especially when it comes to time-space relationship. By introducing temporality into the analysis of 'the urban', de Certeau talks about strategies and tactics. The strategies are always based on the space and we can call them permanent, they seem to be imposed and top down, while the foundations of tactics is time that makes them "forms of everyday creativity" (Chase, Crawford and Kalinski,1999:9) or as Lydon and Garcia explain, "response of the weak" to strategy as "a formal tool of the powerful." (Lydon and Garcia, 2015:43).In sociological sense 
that means changing the direction of urbanism toward local community as one of the key actors of sustainable urban transformation. If we define urban transformation as "ongoing process of making and remaking our cities" through "ideal goals of urban planning... such as: economic growth, environmentally sustainable development and social justice" (Wise and Clark, 2017:1) we can connect that shift from strategy to tactics and its popularity to the beginning of mainstream glocal politics where previously established concept of "park" and "greenery", as a top down approach of urban planning, changes. The management sector is rapidly turning to participation as a key precondition of development of the so called temporary urbanism(s) on the one hand, and socially sustainable urban communities, on the other hand.

The number of types of urbanism is already that big that it requires a proper typology that would facilitate orientation in semantic chaos. Barnett (2011) has divided a total of 60 types of urbanisms in six categories: system urbanisms, green urbanisms, traditional urbanisms, community urbanisms, sociopolitical urbanisms and headline urbanisms. Taking into account the concept of urban gardens that is analyzed in this paper, we have to emphasize the vast amount of green and community urbanisms. In the category of 'green' there are; ecological, landscape, sustainable, environmental, clean and agricultural urbanisms, while in the community urbanisms Barnett puts 17 different types; participatory, consumer based DIY, informal, open source, opportunistic, and then guerilla, gypsy, instant, pop-up, temporary, everyday, exotic, radical, bircole, magical and slum urbanisms. Although not included in Barnett's classification, there are also tactical urbanism, bottom-up urbanism, performative urbanism adaptive urbanism, and the so-called screensaver architecture (Moore, 2015).This amount of different types of urbanism goes in favor of the complexity of the phenomenon, and the fact that the listed terms are not mutually exclusive shows that, when it comes to contemporary urbanism, we actually talk about numerous processes that simultaneously, and more or less connected, are happening in the city at any given moment.

Based on definitions of green and community urbanisms we can conclude that they differentiate in 3 aspects; whether they are part of public policy or are independent, whether they are related to temporary or permanent change of space and whether they change, complement or renew certain urban space.

Although the urban gardens are often linked to the concept of guerilla urbanism (Rubić i Gulin Zrnic, 2015) this study concentrates on the space-time segment of the transformation of perception of urban greenery, which we observe from the pop up urbanism perspective. Realizing the pop up phenomenon as part of a temporary urbanism, the name itself indicates that the volatility and the changing nature of these types of urbanisms are key features that share common characteristic of being "alternative form of urban development" (Barnett, 2011).Avoiding any further conceptual differences analysis of various types of temporary urbanism, pop-up urbanism separates itself from other types by being not exclusively limited to improving public spaces, but involving different public and commercial events, along with community projects. Exactly this aspect allows the reciprocal relationship between the public and the private, resulting in introducing the general public to transformation of the city. 
Harris defines pop-up geographies through three aspects: interstitiality, flexibility and immersion. Flexibility refers to the dual ability of pop up to relocate a specific place to another location or to use a specific location for the creation of different places at different times.Interstitiality, as a characteristic of pop up urbanism, further defines the concept "as spaces of alterity, disrupting both the rhythms and Aesthetics of city spaces by repurposing sites temporarily (...)"(Harris, 2015:596). By filling the gaps in the urban tissue, Harris believes that pop up spaces "challenge ideas" about space and time while emphasizing that further event-full of pop up urbanism, which brings around the fact that something is happening in the city. All kinds of events are often organized and "makes possible the weeding-out illegal or undesirable occupation of interstices" (Harris, 2015:598). The perception of urban design through different types of social events is one of pioneering forms of integration of social life in urbanism. The whole urban development is characterized by some form of temporary urbanisms, through festivals, processions, fairs and various urban rituals that have left a mark on the urban tissue. "These spectacles ignited the imagination of the public officials and citizens, and functioned in a short time-span as urban design proposals for improvements to towns and cities" (Sotelo, 2013:16).

The last aspect of pop-up urbanism is immersion which refers to the experience of a certain place that pop up urbanism transforms by creating a new or slightly modified image of a specific place in town that opens itself to its customers which emphasizes "the way those experiences work to reimagine and reshape the city". Such a temporary, pop-up type of urbanism also includes urban gardens i.e. numerous versions of the same. The temporality, as a key feature of contemporary urban allotment garden, seemingly removes the requirement of rigid spaciousness, but at the same time allows for one traditional category, such as garden, to be transformed into a hyper modern, while carrying in itself key features of urban space today: temporality, mobility and availability. Although allotment gardens are not a new phenomenon, if understood as part of the new urban concepts they fit into the urban trend that is being developed and is based on participation and the re-creation of nature into the city. Since it floats somewhere between space and time, pop up urbanism can be analyzed as a bond of tactics and strategy regarding aforementioned characteristics. Exploring the transformation of perception on urban greenery through the most general terms, parks and gardens, we are trying to analyze the concept of temporal through variable pop up urbanism, which floats between top down and bottom up approach, and an integral part of any urbanism, everyday life of course

\section{Park vs. Urban Allotment Garden}

The integration of nature into urbanism is a historical aspect of development of every city. It can be traced back all the way from the emergence of the first cities and great civilizations of Egypt, Greece and Rome that have, over the centuries, created different types of "nature" of the city, to the emergence of garden city movement and the modern city as we know it nowadays. Urban allotment gardens as well as parks are spaces in the city in which multitude of dimensions are intertwined. Thus, the concept and practice of urban allotment gardens and parks in the research discourse can be discussed through: 
1. Environmental dimension: greening the city, production of foods, eating organic as well as minimizing the time of food transportation (from production to table);

2. Social dimension - the terms community garden or public park is often used in the name itself to emphasize the function of community, which is an important aspect of both; within this dimension we can talk about the economy of the urban gardens as well as about the various city policies that ease or complicate the development of urban greenery;

3. Urbanistic dimension - in which we deal with the space in which urban gardens and parks exist as well as the architecture and aesthetics of them together with design and usage.

Taking into consideration the historical aspect and the different typologies, but also architecture, green zones of cities are part of, what we today call, the urban phenomenon and their importance in terms of sustainability is being analyzed increasingly. "Gardens and parks - as important parts of cities' green zones - are a reflection of the contemporary culture, and the philosophy and man's relationship toward nature and area of residence and stay" (Šimleša, Butorac, 2007:1084).Apart from being a part of the culture and aesthetics, as well as the "lungs" of the city, parks and gardens are also considered open public spaces. In the category of public space, UN habitat positions them alongside playgrounds, beaches, waterfronts and river banks as "available to all without charge and are normally publicly owned and maintained. In many cases, however, they are accessible during daylight hours only" (2015:27). Although being in the same category, public space, park and garden differentiate: the park is defined as "a piece of public land in or near a city that is kept free of houses and other buildings and can be used for pleasure and exercise" while the garden is defined as "an area of ground where plants (such as flowers or vegetables) are grown” (Merriam-Webster, 2017).

Jurković makes a difference between a park and a garden based on other aspects, the park is «designed space», while the garden is a «certain property», but points out that the terminology is not harmonized (Jurković,2004). The most general definition becomes more complicated when we introduce other terms that are related to park and garden, such as public park and allotment garden. Distinguishing between park and garden as two different forms of urban greenery serves to emphasize the relationship between space and time we previously mentioned. The identity of park as urban and permanent settlement that will show primarily cultural necessity for, according to Jurković, establishing a balance with nature, establishing order, action and selecting, borders with the artistic act, while the identity of the garden as a rural area, in its essence, is about fulfilling the primary function of survival. If viewed from this perspective, park and garden can be seen as conflicting spatial manifestations. What follows, in the contemporary practice, is further blending of the so-called astyphilia (desire for urban life) and the more profound awareness of the different pillars of sustainability that are submerged in the concept of multifunctional everyday life. Crawford additionally emphasizes that relationship by describing everyday life as "zone of social transition and possibility with the potential for new social arrangements and forms of imagination" (Chase, Crawford and Kalinski, 1999:9). 


\section{Local Perspective: A Glance Through Croatian Urban Gardens}

Despite a long tradition of urban parks, the phenomenon of urban gardens in Croatia is a relatively new phenomenon in comparison to some other more developed Western countries. As a topic in public discourse it is imposed only sporadically, mainly within the narrow circle of professionals, so it's not surprising that urban gardening, as a subject of scientific study in Croatia, is still in its infancy.

On the other hand, research on architecture of parks, history and urbanism of parks, is a much more prevalent theme in Croatian academic community. Parks are studied as part of the cultural and architectural heritage, as elements of cityscape, as garden art, and as part of public space (Jurković, 2004; Obad Sćitaroci and Bojanić-Obad Šćitaroci, 1996). Research on parks can be done from agronomic, architectural and sociological perspective, but regardless of starting point, it is clear that parks are one of the par excellence urban elements. Croatian cities have a long tradition of park architecture and most of cities' parks and gardens are carefully designed and integrated in urbanism of cities. Nowadays they are part of the urban identity, but their reconstruction and revitalization rarely satisfy citizens.

Considering the widest range of academic literature on urban gardens showed that this topic has aroused interest in various disciplines, especially in the spectrum of social and humanity sciences such as ethnology of everyday life, urban sociology, cultural geography, urban anthropology, landscape architecture, etc., leading to the fact that this subject is being approached interdisciplinary more often.

While dealing with the alternative urbanization and identities of new areas, ethnologist Dunja Rihtman -Augustin, in her book Ethnology of our everyday life (1988), was among the first, in the Croatian scientific context, to mention and reflect on the so-called wild gardens i.e. vegetable gardens in Zagreb. They are created in the suburbs or in neglected, unregulated parcels in the city, as a result of the processes that can be considered predecessors of bottom-up approach in Croatia. According to author, the practice of urban gardening is the result of heterogeneous phenomenon of alternative urbanization and the process of usurpation of the city (RihtmanAuguštin, 1988).

Researches on forms of engaged relationship toward the space and the town as a whole along with cultural-anthropological considerations of different cultural codes that make daily life in an urban context, have led author Gulin Zrnić to recognize urban gardens as an important factor in the process of developing social practices in public spaces that create everyday living in the smaller urban units such as neighborhoods / districts (Gulin Zrnić, 2012).

The phenomenon of urban gardening in the city is analyzed with a special attention to different types of gardens - "wild" gardens that were created in the squatted urban land by individual initiatives and community gardens that were organized mostly by civil society organizations, with a special attention on different aspects of the investment in the development of urban gardens (Biti, Blagaić Bergman, 2014). 
Sociologists emphasize possible potential of having "the nature in the city" as a public good in the context that is marked by "privatization processes, fencing, excessive regulation and organization, and especially excessive construction, thus losing the essential element of 'the natural' in a town. Its natural presence offers exactly that while providing an important aesthetic and perceptive dimension and usefulness for residents of urban areas" (Čaldarović and Šarinić, 2010).

Butorac and Šimleša (2007) have, in their work, problematized increasingly evident reduction of public space and green areas and the impact of the profit on the creative process of designing some spaces including parks. While considering the phenomenon of urban gardens from a sociological perspective, they treat urban gardens as something special within the green zones because of the role they have in the economic, social- therapeutic and ecological sense.

In a somewhat more indirect way, but thematically linked, Puđak (2011) warns about the importance of organic farming as an alternative approach to food production which implies specific social relations to nature and technology. In the authors' opinion, conventional agriculture has contributed to global environmental problems. Therefore, we should encourage organic farming practice as a healthier way of life and as a survival strategy for rural and urban population, where urban gardens can definitely have their role.

\section{Results}

\subsection{Methodology}

Trying to integrate theoretical concepts of multitude of modern urbanisms with the relationship of parks and gardens in the urban space while taking into account the call for participation and, increasingly popularized, bottom up approach, we explored attitudes and perceptions of future professionals in the field of architecture and urbanism, the students of Faculty of Architecture, from the University of Zagreb. The question that we brought to the fore is whether urban allotment gardens in the city can provide something really new and to which extent they would change the image of the city and urbanism as a way of life. We were also interested in what kinds of benefits they provide to the local community and socially sustainable development of the city.

Empirical research was conducted on 98 students of architecture and sample included total population of first year masteržs degree students. Questionnaire had 26 mostly closed questions that coveredthree main issues: difference between concepts of urban garden and park, attitudes on urban garden concept and visions for urban garden development. Statistical analysis included descriptive statistics and more complex techniques such as sematic differential and factor analysis. All data was processed in SPSS 19. 
Distribution of male and female respondents was 30.6\% male and 69.4\% female. Most respondents $(71.5 \%)$ have spent childhood in the urban environment while $17.3 \%$ respondents grew up in the rural setting and $11.2 \%$ in the suburban environment. However, half of respondents (55.1\%) grew up in the family house that included garden and 44.9\% respondents lived in apartment buildings.

\subsection{Analysis}

Assuming that gardens and parks are, in their different manifestations, part of urban elements, we analyzed the status of a garden and a park in correlation to other open public spaces such as squares, streets, coasts and boardwalks, playgrounds and marketplaces. When compared to other elements of the city's open spaces, a garden is, according to respondents, the least important element of the city $(57.2 \%)$, its status in the urban structure has not yet been clearly defined, while the park (99\%) is the most important public space in a city (fig.1). The difference is even more apparent when we isolate the answer extremely important and we can see that when compared to other urban structures the garden is considered irrelevant.

Figure 1.

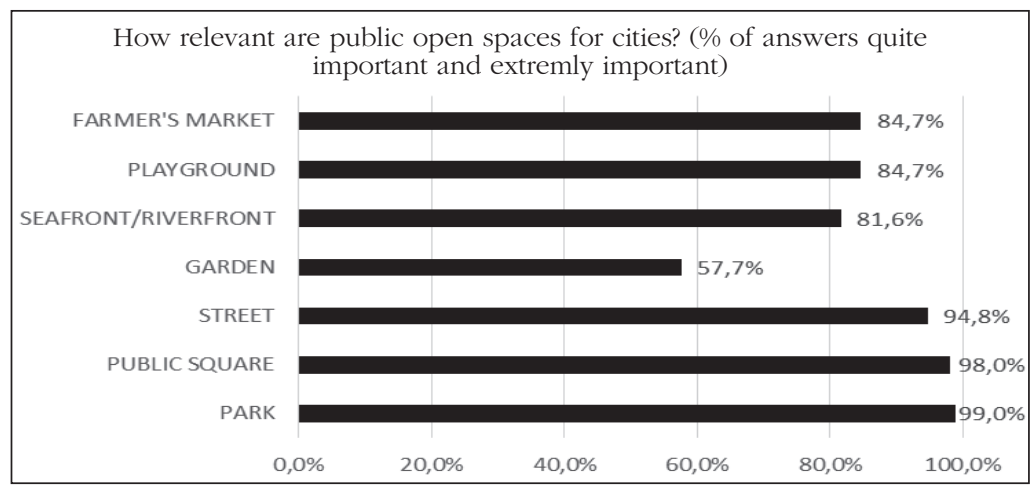

These results indicate the obvious conceptual and semantic distinction between the two terms which, as we have seen in the literature, are often perceive as synonyms. However, the difference between the notion of urban parks and gardens as two separate categories cannot be read from this ranking of the importance of open space area in the city. Using semantic differential as a method which can show semantic differences between concepts, respondents rated park and urban garden through sixteen bipolar pairs: traditional- modern, old-new, rural-urban, spontaneous -planned, close-far, warm-cold, natural - artificial, open-closed, uniforms-multiform, beautiful-ugly, attractive-repulsive, weak-strong, interesting-boring, useful-useless, stimulating- disincentive, static-dynamic (fig 2.).

Very high percentage(91.7\%) of the respondents evaluated park as open, while $87.5 \%$ respondents perceive it as beautiful, $85.5 \%$ as useful, $84.6 \%$ as attractive, $68.1 \%$ as urban and $64.9 \%$ as planned space. 
When it comes to the term garden, $85.5 \%$ respondents evaluated the term as primarily new, followed by attributes such as modern (84.5\%), urban (80.4\%), useful (79.3\%) and attractive (75.1\%).

Distinguishing between the two concepts is mostly evident in open - closed and static - dynamic pairs where the park is significantly more open, probably as traditionally being a public space, and urban garden is more dynamic, a place that adapts to the urban tissue, which makes it close to the pop -up concept. Also, it is evident that the urban garden is perceived as a new socio - spatial element in the urban context.

Figure 2.

Sematic differential on park and urban allotment garden (mean)

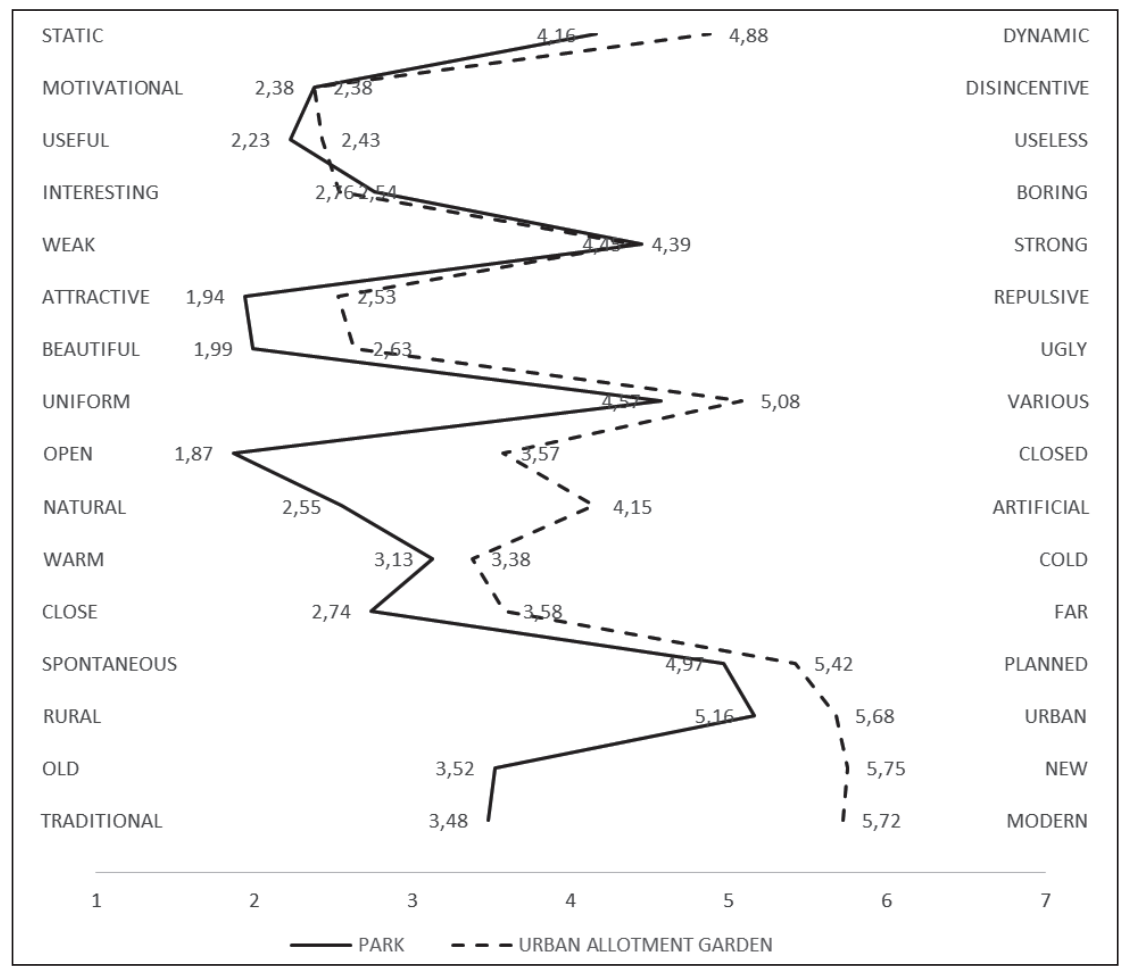

The same concepts were used in another statistical method, factor analysis, which was used to determine the possible different groupings of adjectives that could deepen the understanding of the perception of our operational concepts of a park and an urban garden and we tried to group the results in groups of functional and formal potentials of these different urban spaces. In the case of the term urban garden factor analysis showed three factors that explained $52,3 \%$ of variance. In the first factor, $27,3 \%$ of variance, the following factors were grouped; beautiful - ugly, repulsive - attractive, interesting - boring, stimulating - unstimulating that altogether connect aesthetics to activity in a specific area, and talk about the urban garden 
function in terms of relaxing recreational potential with contribution to the aesthetics of the overall image of the city.

Garden's importance for city is explained by another factor, 16,5\% of variance, which contains three pairs; traditional - modern, old and new , and rural- urban. We called this factor the identity potential of urban gardens, since it's about the contribution that a garden has as a specific kind of form in the urban structure. Modern paradigm of urban garden transforms the traditional perception of the garden towards the modern, new and urban, while having in mind that in Croatia the tradition of the garden in a town is dominantly marked by public park and private garden.

The third factor is the one regarding the space - time category or dynamic potential of urban garden. It explains $8,4 \%$ of variance, including two pairs; monotonous various and static - dynamic, that in the case of an urban garden goes in favor of diversity and dynamism of the space of urban garden, as an element of modern temporary urbanisms with multiple potentials.

When it comes to the perception of the park, the situation is somewhat different. Factor analysis, which explains 51\% of variance, identified three factors, but grouped them differently than they were grouped in the case of the urban garden. The first factor, $28,6 \%$ of variance, includes pairs monotonous-various, interesting boring and static-dynamic, thus making itself dynamic potential of the park whereas the elements of nature contribute to the dynamic of the dominantly artificial (built) city environment.

Another factor, 13\% of variance, includes two pairs of adjectives, those being usefuluseless and stimulating-disincentive that in the case of the park represent (re)creation / (re)creative potential. The table shows that the respondents experienced park as useful (85.5\%) and stimulating (82.5\%), so we can conclude that the park is seen as a good source of (recreational) active potential. The third factor, 9,8\% of variance, includes two pairs of adjectives, attractive-repulsive and beautiful-ugly, and makes aesthetic potential of the park which, as mentioned earlier, is one of the significant qualities of the park.

Since respondents perceive urban garden as sort of an urban novelty, as opposed to, let's say park, which is more traditional type of designing the urban landscape, we wanted to know what the most important functions urban garden has, for both, urban space and residents of the city that participate in the activities of urban gardens. According to the respondents, the most important function of the garden by far is a therapeutic one, relieving stress and relaxing (93.9\%), which corresponds to the experience of an urban garden as a popular and contemporary space that could help solve the equally popular and contemporary urban problems - stress. Another important function, according to our respondents, is to increase greenery in cities (79.6\%), thus increasing the chances for the realization of ecological optimum and ensuring optimum living conditions. Socializing (73.4\%) is the next one, highlighting the social role that a garden has. It is interesting that the respondents singled out savings on food (33.6\%) and healthy food supplies (44.9\%) as the least important. 
Those two functions were shown in other studies as the most important arguments in participating in urban garden activities (fig. 3).

Figure 3.

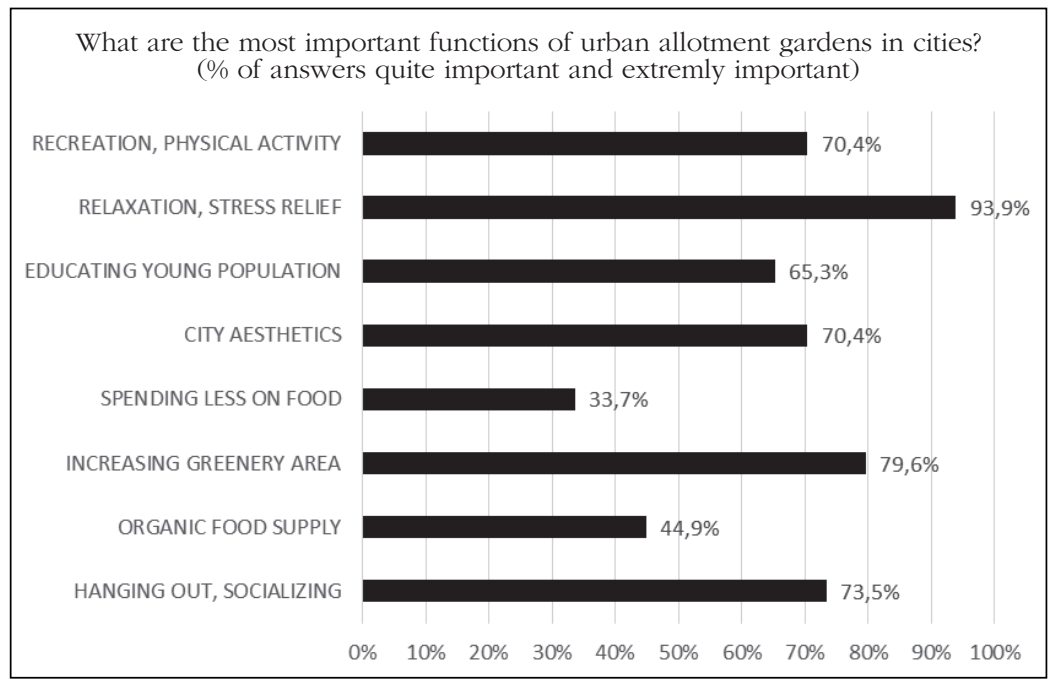

These results continue to confirm that architecture students recognize the social and relaxing potential of a garden, whereas conceptually they haven't moved from what traditional park offers to a city. The economic and nutritional importance have not yet been recognized as a compelling argument for the acceptance of urban gardens.

According to respondents, the biggest obstacle for the concept of urban gardens to come to life in Croatia are the regulations and the decisions of the city administration (66.3\%), followed by a lack of time (64.3\%) and a lack of interest among the citizens $(63,3 \%)$. Criticism against the city government, in this case, is actually criticism of top-down approach which often requires breaking administrative barriers. However, it is important to emphasize that there is a significant progress regarding regulations on urban allotment garden as from 2013 city administration made it legal to rent urban allotment plots. Despite that, there is a collective perception that bureaucratic obstacles that often complicate efficient and flexible management of the city in general and that goes in favor of the growth of new practice of temporary and pop up gardens that do not require specific bureaucratic millstone. The following obstacles are part of the phenomenon of contemporary everyday sociology in which the problem of (free) time is connected with the inability to develop specific interests that would connect members of the community or neighborhood. In the case of Croatia, according to the respondents, the process of the revitalization of the city while using contemporary green urbanism, is facing two types of obstacles, topdown and bottom-up, due to the lack of interest that would guarantee more specific results. However, one should have in mind that these are attitudes and perceptions of just one group of professional community, which can be interpreted in the light of personal participation interests, in the practice of urban gardens, whether it's about 
a professional interest or personal motivation for urban agriculture. Having this in our minds, we asked respondents about their participation in the urban garden, and the results showed that huge majority have no active involvement in urban gardens (94.9\%), and that a large part of them would be willing to make time once a month $(39.8 \%)$ or a week $(33.7 \%)$, to work in the garden.

Besides their personal involvement, we also asked students of architecture who, according to them, should play a crucial role in making decisions about integrating urban gardens in the urbanism of a town (fig.4). Citizens and civic initiatives (90.7\%) and architects and urban planners (88.7) are the ones. Citizens and professionals working together goes in favor of bottom-up approach. When it comes to city administration, the respondents believe that decisions about urban gardens should be left to micro-local level, i.e. local, and block committees (85.4\%).

Figure 4.

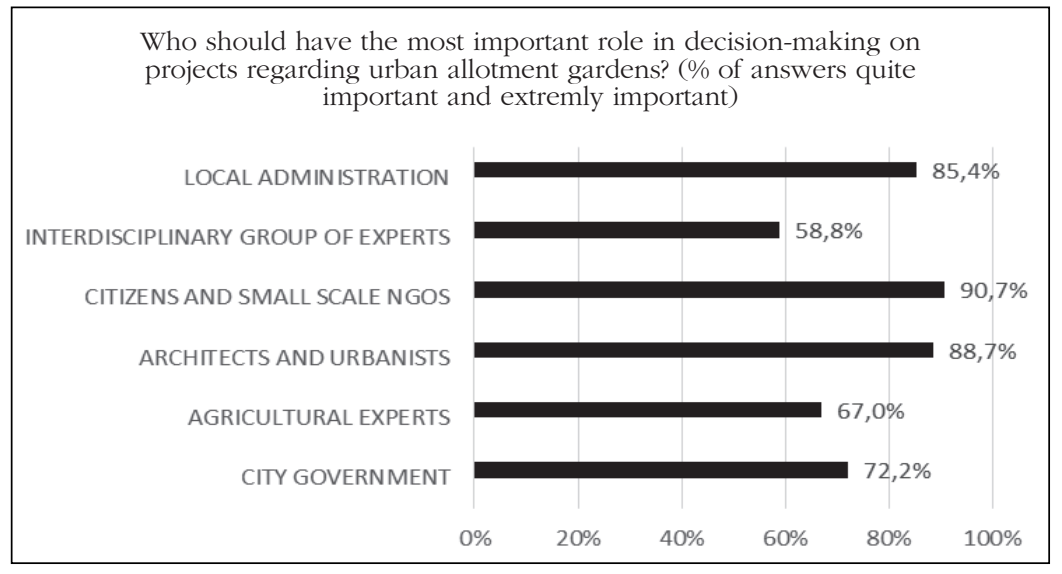

Despite above mentioned, respondents felt that the urban gardens, as one element of town in urban and spatial planning, were dealt with slightly (43.9\%) or not at all $(35.7 \%)$.

The most appropriate place for urban gardens, for the greatest number of respondents (68.4\%), is on the roofs of buildings. The can be viewed as the mainstream approach, with regard to a large number of modern buildings being designed in such a way to incorporate some form of greenery, from green roofs to the tropical forests on the upper floors, usually for the purpose of environmental sustainability. The next most desirable locations are suburbs and family houses with infield (67.3\%), neglected parks and shores of rivers, lakes and sea (66.3\%) green areas between buildings (61.2\%). It turns out that desirable locations could be characterized as less visible locations or private places.

Urban centers (23.3\%) are the least adequate locations for urban gardens. These results show that there is a noticeable tendency of respondents to keep urban gardens in the area that is underused or vast or hidden and that they are not willing to 
sacrifice previously designed or constructed open space, especially if it is center of the city.

By analyzing these results it is clear that respondents' interest to participate in the field of designing urban gardens exists, particularly when it comes to professional engagement. However, one can also easily conclude that the future experts in the field of architecture and urban planning perceive the value of urban gardens more through the prism of park architecture, with regard to recreation, relaxing,(non) aesthetic and design aspects, than through environmental and nutritional value of urban gardens.

\section{Conclusion}

Urban gardens nowadays are considered a phenomenon that could unite various requirements of postmodern urbanism: environmental and social sustainability, flexibility, mobility, temporality, the participation of local communities, sensitivity to context, and rediscovering human scale in a mass society. They are certainly one of the bearing elements of modern reconceptualization of urban space, whose advantage is the possibility of localization and incidence in different forms. In this paper, we dealt with paradigm shift from the architecturally-designed parks and gardens and other urban greenery to urban allotment gardens as part of the movement of "temporary" urbanisms, while questioning the terms urban garden and park within the contemporary context and including possibilities of innovative forms of greenery in the urban space along with their numerous functions.

Despite recognizing the phenomenon as "modern, new and urban", respondents' perception of possible social functions of urban garden, and its position in relation to other public locations, is relatively conservative. Although there is a desirable alliance between citizens and professionals, which are highlighted as main performers of promoting urban gardens, students of architecture leave the impression that they cannot fully present mobilization capacity of urban garden for the inclusion of local community in participatory processes, nor can they present the suitability of the concept for the restructuring of urban forms. The reason for the fact that they still see urban allotment gardens within the traditional "green space" can be found in the lack of initiatives and experiences of promoting urban allotment gardens in Croatian cities. Although in the hierarchy of open urban spaces its status is not yet clearly defined, the results showed that in the perceptions of students of architecture urban allotment garden differs from a traditional park in dynamism, diversity and temporality, making it compatible contemporary approach of pop-up urbanism and opens up possibilities for innovative management of urban areas. Undoubtedly, urban allotment gardens have the potential to be vital elements of a modern dynamic town, since they themselves create open concept that flexibly responds to the rapidly changing context. Leaning on a long tradition of integrating parks in the city structure, urban allotment gardens have responded to the transformation of the contemporary city in an innovative and dynamic way.Abandoning rigid spaciousness and static of classic parks, while transcending the usual concept of urban greenery, 
urban allotment gardens nowadays reflect temporality, mobility and availability of contemporary urban spaces and reveal themselves as a trump card of socially and environmentally sustainable city.

\section{References}

1. Bagaeen, S. (2006). Redeveloping former military sites: competitiveness, urban sustainability and public participation. Cities, 23 (5): 339-352.

2. Barnett, J. (2011). A Short Guide to 60 of the Newest Urbanisms. Planning Chicago, 77, 4: 19-21.

3. Biti, O. and Blagaić Bergman, M. (2014). Urbani vrtovi u Zagrebu - ulaganja i izloženost, inicijative i perspektive. Sociologija i prostor, 200 (3): 261-277.

4. Bishop, P. and Williams, L. (2012). The Temporary City. London: Routledge.

5. Butorac, M. and Šimleša, D. (2007). Zelena srca gradova- važnost vrtova i perivoja u urbanim područjima. Društvena istraživanja, 16 (6): 1081-1101.

6. Chase, J.; Crawford, M. and Kaliski, J. (1999). Everyday urbanism: Featuring John Chase. New York, N.Y: Monacelli Press.

7. Čaldarović, O. and Šarinić, J. (2010). Socijalna važnost prirode u urbanom kontekstu. Društvena istraživanja, 108/109: 733-747.

8. Duaney, A. (2015). in: Lydon, M. and Garcia, A. (Eds.). Tactical Urbanism: Short-term Action for Long-term Change. Island Press.

9. Elin, N. (1999). Postmodern urbanism (revised edition). New York: Princeton Architectural Press.

10. Gulin Zrnić, V. (2012). Gradski mali vrtovi - urbane heterotopije. Zarez, 14/345:

11. Harris, E. (2015). Navigating Pop-up Geographies: Urban Space-Times of Flexibility, Interstitiality and Immersion. Geography Compass, 9/11: 592-603.

12. Jurković, S. (2004). Park ostvarenje sna. Teorija vrtne umjetnosti. Zagreb: Naklada Jurčić d.o.o.

13. Merriam-Webster, Inc. (1996). Merriam-Webster dictionary online. Springfield, Mass: Merriam-Webster.

14. Moore, T. (2015). Screensaver Architecture. Volume 43: 4-9.

15. Moore-Cherry, N. (2016). Beyond art in 'meanwhile spaces': Temporary parks, urban governance and the co-production of urban space, in: Murzyn Kupisz, M. and Działek, J. (Eds.). The Impact of Artists on Contemporary Urban Development in Europe. Netherlands: Springer.

16. Obad Šćitaroci, M. and Bojanić-Obad Šćitaroci, B. (1996). Parkovna arhitektura kao element slike grada. Prostor, 4 (1/11): 79-94.

17. Puđak, J. and Bokan, N. (2011). Ekološka poljoprivreda -indikator društvenih vrednota. Sociologija i prostor, 190 (2): 137-163.

18. Rihtman-Auguštin, D. (1988). Etnologija naše svakodnevice. Zagreb: Školska knjiga.

19. Rubić, T. and Gulin Zrnić, V. (Ed.) (2015). Vrtovi našega grada: Studije i zapisi o praksama urbanog vrtlarenja. Zagreb: Institut za etnologiju i folkloristiku, Hrvatsko etnološko društvo.

20. Sotelo, F. (2013). Beyond the Ephemeral: Preserving the Existing Built Environment with Temporary Urban Interventions. Columbia University Academic Commons. http://hdl.handle.net/10022/AC:P:20678. 
21. Tunström, M. (2007). The vital city: constructions and meanings in the contemporary Swedish planning discourse. Town Planning Review, 78, 6: 681-698.

22. UN Habitat (2015). Global Public Space Toolkit From Global Principles to Local Policies and Practice. http://unhabitat.org/books/global-public-space-toolkitfrom-global-principles-to-local-policies-and-practice/.

23. Wirth, L. (1938). Urbanism as a way of life. American Journal of Sociology, 44 (1): 1-24.

24. Wise, N. and Clark, J. (2017). Urban transformations: Geographies of renewal and creative change. New York, NY: Routledge. 
Prethodno priopćenje

Sara Ursić

Institut društvenih znanosti Ivo Pilar, Zagreb, Hrvatska

e-mail:sara.ursic@pilar.hr

Rašeljka Krnić

Institut društvenih znanosti Ivo Pilar, Zagreb, Hrvatska

e-mail: raseljka.krnic@pilar.hr

Anka Mišetić

Sveučilište u Zagrebu, Arhitektonski fakultet, Studij dizajna, Hrvatska

e-mail:anka.misetic@arhitekt.hr

\section{Urbani vrtovi - privremeni urbanizam i koncept privremenog urbanog vrta}

\section{Sažetak}

U kontekstu suvremenog grada, koncept i praksa urbanih vrtova predstavljaju jedan od ključnih alata za postizanje gotovo univerzalnog cilja svakog urbanog prostora: održivost $\mathrm{i}$ „smartness". Osim toga poziv za reorganizacijom i otvaranjem napuštenih, neiskorištenih ili zapuštenih prostora u svrhu proširenja javnog prostora već je dugo dio istraživanja urbanih studija u potrazi za ravnotežom unutar urbanog prostora. Taj zahtjev i mainstream popularnost doveo je i do početka svojevrsne institucionalizacije urbanih vrtova koji su danas često dio prostornih planova i urbanih politika, mijenjajući ustaljeni koncept „parka“ i „zelenila“ kao top down pristupa urbanog planiranja.

Istovremeno na urbanoj prostornoj sceni svjedoci smo pojave privremenog urbanizma čiji su osnovni ciljevi privremeno korištenje gore opisanih prostora za širok spektar aktivnosti koje variraju od formalnih do neformalnih. Privremenost urbanog vrta kao njegova ključna osobina naizgled ukida zahtjev prostornosti, ali istovremeno omogućava da se jedna tradicionalna kategorija kao što je vrt transformira u hiper suvremenu noseći u sebi ključne osobine urbanog prostora danas: privremenost, mobilnost, dostupnost.

Danas u većini Hrvatskih gradova postoje urbanih vrtovi, a mnogi gradovi su i institucionalizirali njihovo postojanje. Kada je u pitanju prostorno uređenje i dizajniranje urbanih vrtova, posebnu pažnju zauzimaju upravo privremeni urbani vrtovi kao dio građanskih inicijativa ili festivalskih događanja čija je funkcija širenje popularnosti urbanih vrtova posebno među mlađom populacijom.

Imajući na umu mnogobrojne, često bipolarne dimenzije urbanog vrta, u ovom istraživanju analizirali smo stavove studenata arhitekture o konceptu, korištenju i oblikovanju urbanih vrtova u Hrvatskoj kroz nekoliko operacionalnih kategorija kao što su prolazno-stalno, amaterski-profesionalno, bottom-up - top-down te prostor-mjesto.

Ključne riječi: privremeni urbanizam, urbani vrtovi, prostor, mjesto. 